\title{
Histological changes and immunolabeling of Leishmania infantum in kidneys and urinary bladder of dogs
}

\author{
Alteraçôes histológicas e imunomarcação de Leishmania infantum em rins e bexiga de cães \\ Jamile Prado dos Santos ${ }^{1}$; Leucio Câmara Alves ${ }^{1}$; Rafael Antonio Nascimento Ramos ${ }^{1,2 *}$; Danillo de Souza Pimentel ${ }^{1}$; \\ Gílcia Aparecida de Carvalho ${ }^{3}$; Maria Fernanda Melo Monteiro ${ }^{1}$; Maria Aparecida da Gloria Faustino ${ }^{1}$ \\ ${ }^{1}$ Laboratório de Doenças Parasitárias dos Animais Domésticos, Departamento de Medicina Veterinária, Universidade Federal Rural de \\ Pernambuco - UFRPE, Recife, PE, Brasil \\ ${ }^{2}$ Dipartimento di Medicina Veterinaria, Università degli Studi di Bari, Valenzano, Bari, Italy \\ ${ }^{3}$ Unidade Acadêmica de Garanhuns, Universidade Federal Rural de Pernambuco - UFRPE, Garanhuns, PE, Brasil
}

Received January 22, 2013

Accepted March 20, 2013

\begin{abstract}
The aim of this study was to assess histological alterations and perform immunolabeling of Leishmania infantum in the kidneys and urinary bladder of naturally infected dogs. Twenty-five urinary bladder and kidney samples of serologically positive animals (ELISA $S 7^{\circ}$ Biogene and IFAT $\geq 1: 40$ - Biomanguinhos/Fiocruz) were analyzed by means of immunohistochemical and histological techniques. Cystitis was found in $44 \%$ (11/25) of the bladder samples and membranoproliferative glomerulonephritis in $92 \%(23 / 25)$ of the kidney samples. Immunolabeling of the parasite revealed that $32 \%(8 / 25)$ of the bladders and $8 \%(2 / 25)$ of the kidneys were positive. In conclusion, the immunohistochemical technique is a useful tool for detecting amastigote forms of $L$. infantum in organs of infected dogs. In addition, this was the first report of detection of amastigote forms of $L$. infantum in the bladders of dogs.
\end{abstract}

Keywords: Leishmania infantum, immunohistochemistry, nephropathy, cystitis, dog.

\section{Resumo}

Objetivou-se neste estudo avaliar as alteraçôes histológicas e realizar a imunomarcaçáo de Leishmania infantum em rins e bexiga de cáes naturalmente infectados. Vinte e cinco amostras de bexiga e rins de animais sorologicamente (ELISA S7 ${ }^{\circ}$ Biogene and IFAT $\geq 1: 40$ - Biomanguinhos/Fiocruz) positivas foram analisadas histologicamente e por meio da técnica de imuno-histoquímica. Os resultados revelaram cistite em $44 \%$ (11/25) das amostras de bexiga e glomerulonefrite membranoproliferativa em $92 \%(23 / 25)$ das amostras de rins. A imunomarcação do parasito revelou $32 \%(8 / 25)$ e $8 \%$ $(2 / 25)$ de positividade em bexiga e rins, respectivamente. Conclui-se que a técnica de imunohistoquímica é uma útil ferramenta para deteç̧áo de formas amastigotas de L. infantum em órgáos de cáes infectados. Além disso, o presente trabalho reporta a primeira descrição de formas amastigotas de L. infantum em bexiga de cáes.

Palavras-chave: Leishmania infantum, imuno-histoquímica, nefropatia, cistite, cão.

Canine Visceral Leishmaniasis (CVL) is an important protozoan disease caused by Leishmania infantum, which is considered endemic in many regions of Brazil (ROMERO; BOELAERT, 2010). Affected animals may present asymptomatic infection or infection with nonspecific clinical signs, such as weight loss, alopecia, cutaneous lesions, conjunctivitis, onychogryphosis, lymphadenopathy and hepatomegaly (BANETH et al., 2008).

\footnotetext{
${ }^{*}$ Corresponding author: Rafael Antonio Nascimento Ramos

Laboratório de Doenças Parasitárias dos Animais Domésticos, Universidade Federal Rural de Pernambuco - UFRPE, Av. Dom Manoel de Medeiros, s/n,

Dois Irmãos, CEP 52171-900, Recife, PE

e-mail: rafaelanramos10@yahoo.com.br
}

Infections caused by this protozoon are characterized by chronic systemic immune-mediated disease, in which the Th1 cell response is associated with asymptomatic dogs exhibiting apparent resistance, whereas the clinical disease is represented by humoral responses (MORENO et al., 1999). Excessive B lymphocyte activity leads to formation of immune complexes (GOTO; LINDOSO, 2004), which are deposited on the walls of blood vessels and in organs, thus favoring development of vasculitis, uveitis, arthritis and, especially, glomerulonephritis and renal failure (LOPEZ et al., 1996; IKEDA et al., 2003).

In the kidneys, deposition of immune complexes in the glomeruli may cause chronic renal failure in dogs, usually characterized by glomerulonephritis, interstitial nephritis and, occasionally, 
amyloidosis (MANNA et al., 2008) with compromised kidney function (LOPEZ et al., 1996). Moreover, a secondary inflammatory reaction, decreased perfusion of the peritubular capillaries and tubular and interstitial tissue ischemia can be seen (LOPEZ et al., 1996). This condition may be found in both symptomatic (POLI et al., 1991) and asymptomatic dogs (CIARAMELLA et al., 1997), and is the main cause of death among these animals (LOPEZ et al., 1996; POCAI et al., 1998).

Little is known about the pathogenesis of infection by L. infantum in relation to the kidney and urinary bladder. Therefore, the aim of the present study was to assess the histological changes and immunodetect amastigote forms of this parasite in the kidneys and urinary bladder of naturally infected dogs.

According to the Brazilian Ministry of Health, animals infected with $L$. infantum should be put down through the Visceral Leishmaniasis Surveillance and Control Program. In this study, 25 dogs that were seroreactive to L. infantum in both serological tests (ELISA $S 7^{\oplus}$ Biogene and IFAT $\geq 1: 40$ - Biomanguinhos/ Fiocruz) were used. The diagnosis was made and the animals were put down by the official epidemiological surveillance service of the city of Bezerros (state of Pernambuco, Brazil), in accordance with the recommendations of the Brazilian Federal Council of Veterinary Medicine.

Following this, fragments of the kidneys $(n=25)$ and urinary bladder $(n=25)$ were removed from each animal for histopathological examination. The samples were placed in $10 \%$ buffered formalin, routinely processed for embedment in paraffin, cut using a microtome into sections of thickness four to five micrometers $(\mu \mathrm{m})$ and stained with hematoxylin-eosin (HE). The macroscopic and microscopic characteristics were observed in all the organ fragments. For immunohistochemical examination, immunolabeling of the amastigote forms of L. infantum was performed using the streptavidin-peroxidase technique, following the method previously standardized (TAFURI et al., 2004). Ear skin from a dog with intense cutaneous parasitism due to L. infantum was used as the positive control in the immunohistochemical analysis.

No alterations were observed in the macroscopic evaluation of the kidneys and urinary bladder. Moreover, it was not possible to visualize amastigote forms of $L$. infantum in any of the fragments in the histopathological analysis on either of the organs.

A total of $44 \%(11 / 25)$ of the urinary bladder fragments exhibited cellular infiltrates. The main alterations observed through the histopathology analysis were lymphohistoplasmacytic and lymphoplasmacytic infiltrates, followed by hypertrophied macrophage infiltrate. The immunohistochemical technique revealed amastigote forms of $L$. infantum in 32\% (8/25) of the bladder samples (Figure 1). Only one of these samples exhibited histological alterations, consisting of an inflammatory reaction in the adventitial layer, characterized by moderate lymphoplasmacytic infiltrate and focal perivascular infiltrate (Figure 2).

Regarding the kidney samples, at least one alteration (e.g. membranoproliferative glomerulonephritis; glomerular degeneration and atrophy (Figure 3); lymphohistoplasmacytic, lymphoplasmacytic or lymphohistiocytic infiltrate; or granulomatous inflammation) was found in the histopathological analysis on each fragment. Cells undergoing apoptosis and Bowmann capsule lesions were alterations commonly observed. Eight percent of the samples (2/25) exhibited

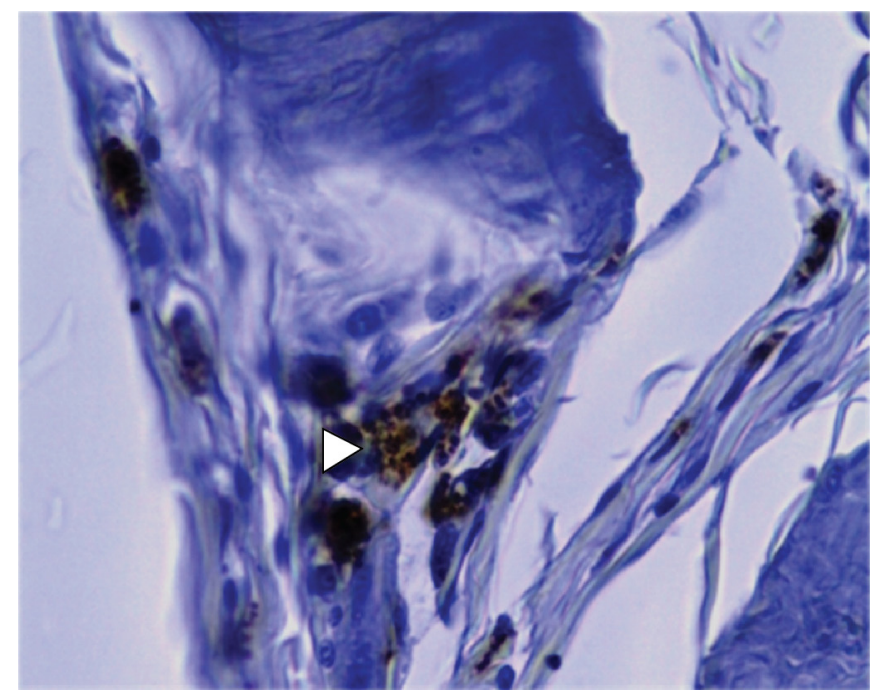

Figure 1. Immunodetection of the parasite in canine urinary bladder, showing intracytoplasmic amastigote forms of L. infantum in adventitial layer bladder (arrow). Streptavidin-peroxidase complex. Obj. $40 \times$.

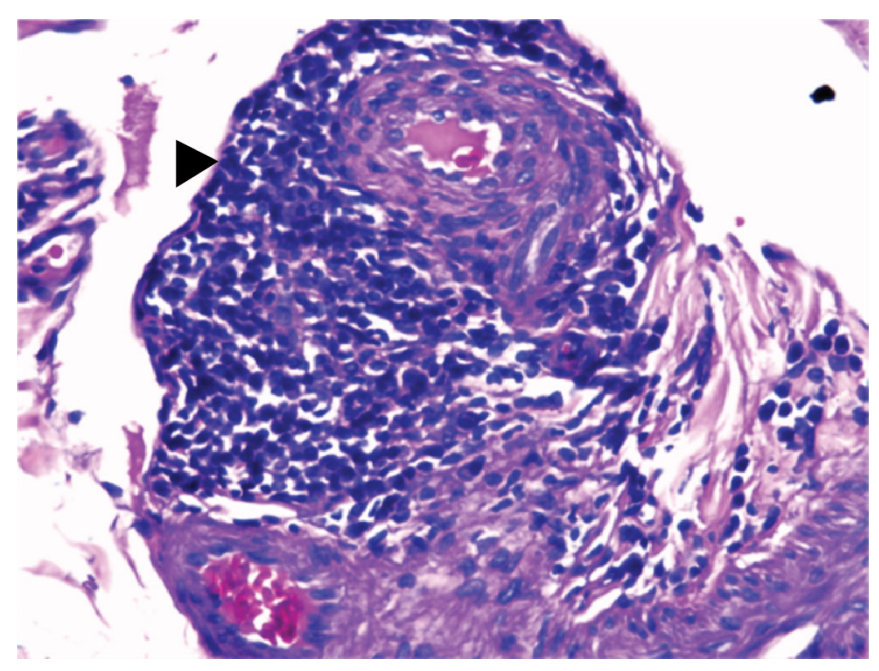

Figure 2. Photomicrograph of the adventitial layer of the urinary bladder in a dog with visceral leishmaniasis. Note the lymphoplasmacytic infiltrate perivascular (arrow). Hematoxylineosin. Obj. 40x.

immunolabeling of amastigote forms of L. infantum (Figure 4) and demonstrated membranoproliferative glomerulonephritis and different degrees of lymphoplasmacytic infiltrate, thus characterizing interstitial nephritis and degeneration of the glomeruli.

Glomerular alterations characterized by thickening of the basal membrane and increased cellularity were a striking characteristic, with occurrences of cells with an apoptotic appearance. Thickening of Bowman's capsules was frequently seen in chronic, advanced lesions, generally associated with protein content in the glomerular space. The distribution of glomerular lesions ranged from focal (involving only one segment of the glomerulus) to diffuse. The glomerulonephritis pattern was membranoproliferative, which is in agreement with previously described findings in dogs with CVL (COSTA et al., 2003). 


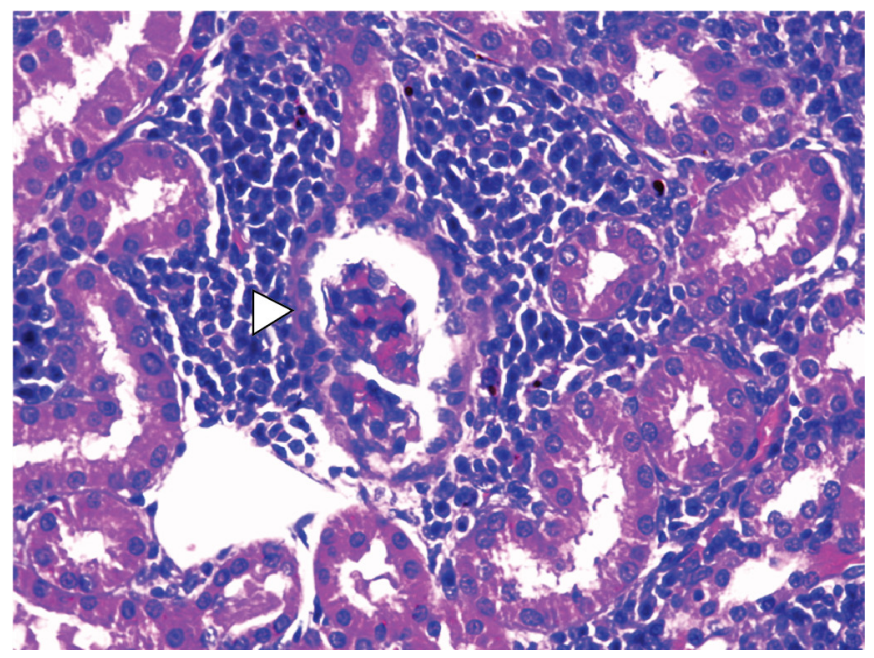

Figure 3. Photomicrograph of glomerular atrophy (arrow) in a kidney in a dog with leishmaniasis. Hematoxylin-eosin. Obj. 40×.

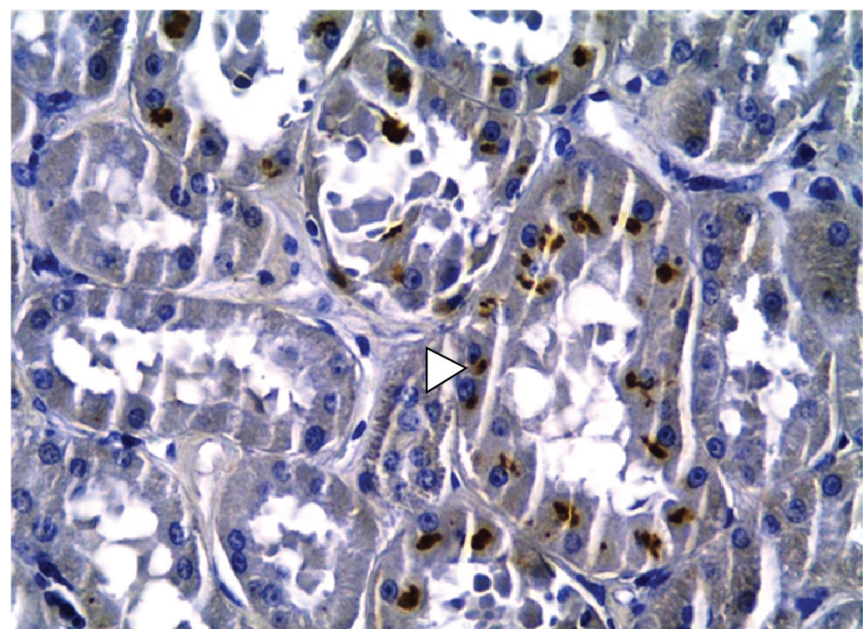

Figure 4. Immunodetection of the parasite in canine kidney, showing intracytoplasmic amastigote forms of $L$. infantum in renal tubular epithelium. Streptavidin-peroxidase complex. Obj. 40×.

The results from the present study confirm that immunohistochemistry is an important procedure for detect L. infantum in different organs (COSTA et al., 2003; TASCA et al., 2009). In addition, it is the first description of the presence of amastigote forms of $L$. infantum in the bladders of dogs.

Cystitis has been reported in dogs infected by $L$. infantum as an opportunistic disease (FEITOSA, 2001; CAVALCANTI et al., 2005). It is likely that the rarity attributed to vesicle impairment in CVL cases is due to the facts that this is a systemic disease with severe clinical manifestations and that little value has been given to urinary signs.

The increased cellularity in the glomeruli, with epithelial and mesangial proliferation, and the deposition of immune complexes in the basal membrane are responsible for inflammatory processes in kidney tissue (JONES et al., 2000). The mesangium plays an important role in the progression of glomerulonephritis, by limiting its repercussion and duration through degradation of the deposited immune complexes. In contrast, release of vasoactive amines enhances vascular permeability, thus making the immune complexes leave the microcirculation and become deposited on the glomeruli, although activation of the alternative pathway in the complement system results in generation of important chemotactic factors that attract neutrophils to the glomeruli (CARLTON; McGAVIN, 1998). Indeed, the selective permeability of the glomerular filtration mechanism is lost in cases of glomerulopathy, and large amounts of serum proteins are filtered (MACDOUGALL et al., 1986; DIBARTOLA; BENSON, 1989). Release of substances that participate in the inflammatory reaction stemming from a glomerular lesion, particularly mesangial cells, and deposition of fibrin (CARLTON; McGAVIN, 1998), may account for the cell proliferation observed in the present study.

In the majority of the dogs, the infiltrate was basically composed of plasmocytes, lymphocytes and macrophages. One sample exhibited a granuloma in the renal parenchyma. From a physiopathological standpoint, the interstitial nephritis found here was an important lesion, considering that altered kidney function is more related to interstitial than to glomerular alterations (BOHLE et al., 1987). The kidney conditions found in the present study, particularly diffuse membranoproliferative glomerulonephritis and interstitial nephritis, may lead to kidney failure, which is considered to be the main cause of death among animals with CVL (POCAI et al., 1998).

The present study also provides the first description of the presence of amastigote forms of $L$. infantum in the bladders of dogs and alerts to the fact that clinical signs stemming from the urinary system should be taken into consideration when diagnosing this disease. Further studies should be conducted in order to better elucidate the clinical implications of the presence of amastigote forms in the urinary bladder.

\section{References}

Baneth G, Koutinas AF, Solano-Gallego L, Bourdeau P, Ferrer L. Canine leishmaniosis - new concepts and insights on an expanding zoonosis: Part one. Trends Parasitol 2008; 24(7): 324-330. PMid:18514028. http:// dx.doi.org/10.1016/j.pt.2008.04.001

Bohle A, MacKensen-Haen S, Gise HV. Significance of tubulointerstitial changes in the renal cortex for the excretory function and concentration ability of the kidney: a morphometric contribution. Am J Nephrol 1987; 7(6): 421-433. PMid:3439552. http://dx.doi. org/10.1159/000167514

Carlton WW, McGavin MD. Patologia Veterinária Especial de Thomson. 2. ed. Artes Médicas Sul; 1998.

Cavalcanti MP, Faustino MAG, Silva LBG, Alves LC. Aspectos clínicos das dermatopatias infecciosas e parasitárias em cães com diagnóstico presuntivo de Leishmaniose Visceral. Clin Vet 2005; 58: 36-42.

Ciaramella P, Oliva G, Luna R, Gradoni L, Ambrosio R, Cortese L, et al. A retrospective clinical study of canine leishmaniasis in 150 dogs naturally infected by Leishmania infantum. Vet Rec 1997; 141(21): 539-543. PMid:9413121. http://dx.doi.org/10.1136/vr.141.21.539

Costa FAL, Goto H, Saldanha LC, Silva SM, Sinhorini IL, Silva TC, et al. Histopathologic patterns of nephropathy in naturally acquired canine 
visceral leishmaniasis. Vet Pathol 2003; 40(6): 677-684. PMid:14608021. http://dx.doi.org/10.1354/vp.40-6-677

Dibartola SP, Benson MD. The pathogenesis of reactive systemic amyloidosis. J Vet Inter Med 1989; 3(1): 31-41. http://dx.doi. org/10.1111/j.1939-1676.1989.tb00326.x

Feitosa MM. Leishmaniose visceral: um desafio crescente. São Paulo: Intervet Pet; 2001. 15 p.

Goto H, Lindoso JAL. Immunity and immunosuppression in experimental visceral leishmaniasis. BrazJ Med Biol Res 2004; 37(4): 615623. http://dx.doi.org/10.1590/S0100-879X2004000400020

Ikeda FA, Ciarlini PC, Feitosa MM, Gonçalves ME, Luvizotto MCR, Lima VMF. Perfil hematológico de cães naturalmente infectados por Leishmania chagasi no município de Araçatuba- SP: um estudo retrospectivo de 191 casos. Clin Vet 2003; 47: 42-48.

Jones TC, Hunt RD, King W. Patologia Veterinária. Manole; 2000.

Lopez R, Lucena R, Novales M, Ginel PJ, Martin E, Molleda JM. Circulating immune complexes and renal function in canine leishmaniasis. Zentralbl Veterinarmed B 1996; 43(8): 469-474. PMid:8921735.

Macdougall DF, Cook T, Steward AP, Cattell V. Canine chronic renal disease: prevalence and types of glomerulonephritis in the dog. Kidney Int 1986; 29(6): 1144-1151. PMid:3747331. http://dx.doi.org/10.1038/ ki. 1986.120

Manna L, Vitale F, Reale S, Picillo E, Neglia G, Vescio F, et al. Study of efficacy of miltefosine and allopurinol in dogs with leishmaniosis. Vet J2008; 182(3): 441-445. PMid:18818112. http://dx.doi.org/10.1016/j. tvjl.2008.08.009
Moreno J, Nieto J, Chamizo C, González F, Blanco F, Barker DC, et al. The immune response and PBMC subsets in canine visceral leishmaniasis before, and after, chemotherapy. Vet Immunol Immunopathol 1999; 71(34): 181-195. http://dx.doi.org/10.1016/S0165-2427(99)00096-3

Pocai EA, Frozza L, Headley AS, Graça DL. Leishmaniose visceral (Calazar): cinco casos em cães de Santa Maria, Rio Grande do Sul, Brasil. Cienc Rural 1998; 28(3): 501-505. http://dx.doi.org/10.1590/ S0103-84781998000300025

Poli A, Abramo F, Mancianti F, Nigro M, Pieri S, Bionda A. Renal involvement in canine leishmaniasis: A light-microscopic, immunohistochemical and electron-microscopic study. Nephron 1991; 57(4): 444-452. PMid:2046828. http://dx.doi. org/10.1159/000186348

Romero GAS, Boelaert M. Control of Visceral Leishmaniasis in Latin America - A systematic review. PLoS Negl Trop Dis 2010; 4(1): e584. PMid:20098726 PMCid:PMC2808217. http://dx.doi.org/10.1371/ journal.pntd.0000584

Tafuri WL, Santos RL, Arantes RM, Gonçalves R, Melo MN, Michalick MS, et al. An alternative immunohistochemical method for detecting Leishmania amastigotes in paraffin-embedded canine tissues. J Immunol Methods 2004; 292(1-2): 17-23. PMid:15350508. http://dx.doi. org/10.1016/j.jim.2004.05.009

Tasca KI, Buzetti WA, Tenorio MS, Paulan SC, Lima FL, Queiroz NMGP, et al. Exames parasitológicos, imunoistoquímicos e histopatológicos para detecção de Leishmania chagasi. Rev Bras Parasitol Vet 2009; 18(1): 27-33. PMid:19500457. http://dx.doi.org/10.4322/ rbpv.01801005 